\title{
Persepsi Dan Partisipasi Masyarakat Kawasan Kampung Warna-Warni Terhadap Upaya Perbaikan
}

\author{
Julisa $^{1}$ *, Parjito ${ }^{1}$, Dwi Fauzia Putra ${ }^{1}$ \\ ${ }^{1}$ Program Studi Pendidikan Geografi, Universitas Kanjuruhan Malang, Malang 65148, Indonesia \\ Email : *Julisa150797@gmail.com,Par_jito@yahoo.co.id,dwifauziaputra@unikama.ac.id
}

Dikirim : 21 Maret 2019

Diterima: 30 Maret 2019

\begin{abstract}
Abstrak: Penelitian ini bertujuan untuk (1) mengetahui upaya perbaikan lingkungan RW 02 Kelurahan Jodipan; (2) mengetahui persepsi dan partisipasi masyarakat terhadap upaya perbaikan lingkungan; (3) mengetahui faktor apa saja yang mendorong dan menghambat patisipasi masyarakat terhadap upaya perbaikan lingkungan; (4) mengetahui keterkaitan spasial pengembangan kampung warna warni terhadap aspek kehidupan masyarakat. Metode yang digunakan dalam penelitian ini yaitu pendekatan fenomenalogi dan untuk jenis penelitian menggunakan deskriptif kualitatif. Informan dalam penelitian ini ada 11 orang terdiri dari ketua RW 02, pengelola wisata dan 9 tokoh masyarakat. Analisis data yang digunakan dengan mengumpulkan data, mereduksi data, menyajikan data dan verifikasi data. Peneliti mengambil fokus di RT 6, 7,9 RW 2 di Kelurahan Jodipan. Hasil penelitian ini yaitu (1) upaya perbaikan lingkungan, meliputi: mengecat dinding rumah dan bekerja sama, membersihkan lingkungan, memasang keramik, mengecat tembok, membangun jembatan Embong, menghiasi tempat berfoto, mengecat pagar dengan beraneka warna, memasang hiasan pintu, dan menambahkan fasilitas tempat selfie; (2) persepsi dan partisipasi masyarakat kampung warna-warni terhadap upaya perbaikan lingkungan, meliputi: membawa perubahan, lingkungan bersih, pemandangan menarik, lingkungan indah, sementara partisipasi yaitu keterlibatan mengecat dinding, mengecat pagar beraneka warna, membuat tempat untuk berfoto dan membersihkan lingkungan; (3) faktor yang mendorong dan menghambat patisipasi masyarakat dalam upaya perbaikan lingkungan: pemahaman, pengetahuan, mendapatkan keuntungan dengan berjualan dan untuk meningkatkan perekonomian, faktor penghambat patisipasi masyarakat yaitu pekerjaan di luar Jodipan, kesalahapahaman/beda pendapat, dan kesibukan pekerjaan; (4) keterkaitan spasial pengembangan kampung warna warni terhadap aspek kehidupan masyarakat: munculnya usaha-usaha kecil sepanjang jalan Jodipan, dan terganggunya ketentraman.
\end{abstract}

Kata kunci: persepsi, partisipasi, keterkaitan spasial

\section{Pendahuluan}

Sebelum terbentuknya kampung warna-warni, Jodipan dulunya merupakan permukiman kumuh. Permukiman kumuh merupakan permasalahan yang dialami oleh masyarakat Jodipan itu sendiri, dengan kondisi rumah yang sudah lama dan warna dinding rumah yang pudar sehingga seperti tidak layak untuk di huni oleh masyarakat Jodipan. Selain itu juga masyarakat Jodipan memiliki kebiasaan buruk yaitu membuang sampah ke sungai sehingga membuat lingkungan menjadi kotor dan kesehatan terganggu.

Jodipan sekarang ini sudah menjadi objek wisata yaitu wisata kampung warna-warni yang terbentuk pada tanggal 4 September 2016, upaya perbaikan lingkungan telah dilakukan oleh masyarakat Jodipan dilihat dari partisipasi masyarakat dalam upaya perbaikan lingkungan yaitu dengan membersihkan lingkungan, mengecat beraneka warna pada dinding, pagar maupun memasang keramik di jalan. Sekarang masyarakat Jodipan telah berhasil mengubah image Jodipan yang dulunya Jodipan merupakan permukiman kumuh sehingga sekarang menjadi objek wisata yang banyak diminati oleh wisatawan. Perubahan perilaku masyarakat Jodipan juga sudah berubah dilihat dari masyarakat tidak lagi memiliki kebiasaan membuang sampah ke sungai. 
Persepsi dan partisipasi merupakan dua hal yang menjadi faktor penting dalam upaya perbaikan lingkungan kawasan kampung warna-warni Jodipan. Menurut Aldilla Adelia (2012), persepsi merupakan pandangan atau pendapat umum individu terhadap sesuatu objek yang menjadi sasaran. Persepsi masyarakat terhadap upaya perbaikan lingkungan Jodipan adalah pandangan masyarakat terhadap upaya perbaikan lingkungan kawasan kampung warna-warni Jodipan. Oleh karena itu pengkajian terhadap persepsi masyarakat sekitar kawasan Jodipan sangat perlu untuk dilakukan guna mengetahui sejauh mana anggapan dukungan yang diberikan oleh masyarakat sekitar terhadap upaya perbaikan lingkungan yang dilakukan.

Menurut Farizi Ramadhan dan Parfi Khadiyanto (2014), adanya partisipasi masyarakat di dalam objek wisata menjadi model yang dipandang ideal bagi objek wisata yang banyak pengunjung wisatawan. Partisipasi masyarakat menjadi model dalam upaya perbaikan lingkungan yang sesuai bagi Jodipan, dalam mengidentifikasi partisipasi masyarakat perlu adanya penstrukturan mengenai tingkat dan bentuk dari partiispasi dalam masyarkat. Faktor yang mendorong partisipasi masyarakat dalam upaya perbaikan lingkungan yaitu pengetahuan terhadap program merupakan pemahaman masyarakat bisa saja dipengaruhi oleh lingkungan masyarakat itu sendiri.

Menurut Lutfi Kristiana Palupi (2014), lingkungan adalah studi tentang gejala dan masalah kehidupan manusia yang ditinjau dari hubungannya dengan lingkungan tempat kehidupan. Lingkungan merupakan pengkajian praktis tentang masalah kehidupan dan masalah lingkungan, yang menerapkan konsep dan prinsip ekologi serta prinsip dan konsep Ilmu Sosial. Upaya perbaikan lingkungan Jodipan sangat penting untuk dilakukan karena merupakan salah satu kegiatan dan usaha dalam menjadikan Jodipan sebagai objek wisata yang banyak dikunjungi oleh wisatan. Oleh sebab itu dengan adanya upaya perbaikan lingkungan membawa kawasan Jodipan semakin maju dan terkenal di Jawa Timur maupun di luar pulau.

\section{Metode Penelitian}

Penelitian ini menggunakan metode kualitatif. Teknik pengumpulan data menggunakan metode observasi, wawancara mendalam dan dokumentasi. Keabsahan data menggunakan triangulasi. Informan ada dua yaitu informan kunci dan informan pendukung. Informan pendukung ada dua yaitu pengelola wisata bapak Ismael Marzuki dan ketua RW 02 bapak Soni Parin, sedangkan informan kunci ada 9 orang yaitu ibu Arningsih sebagai penjual bakso, ibu Ning penjaga tiket masuk, bapak Tefa sebagai tukang parkir, ibu Marni penjaga toilet, ibu Wiwik pedagang minuman dan rokok, bapak Joko pemandu wisata, ibu Maria penjual sosis, ibu Ismah penjual es cream, dan bapak Wempa penjual sembako.

\section{Pengumpulan data}

Pengumpulan data penting dilakukan dalam penelitian, tujuan adanya prosedur dan teknik pengumpulan data agar penelitian yang dilaksanakan lebih terstuktur. Prosedur pengumpulan data merupakan langkah yang paling penting karena tujuan utama peneliti adalah mendapat informasi. Proses pengumpulan data dilakukan melalui wawancara, observasi dan dokumentasi.

Aktor-aktor yang terlibat dalam lapangan yaitu Ketua RW 02 bapak Soni Parin, pengelola wisata bapak Ismael Marzuki sangat diperlukan karena untuk mengetahui upaya perbaikan lingkungan, persepsi dan partisipasi masyarakat terhadap upaya perbaikan lingkungan, faktor pendorong dan penghambat patisipasi masyarakat dalam upaya perbaikan lingkungan 
kampung warna-warni, dan keterkaitan spasial pengembangan Jodipan terhadap aspek kehidupan masyarakat Pengelola wisata. Selain itu juga alasannya adalah untuk menambahkan pemahaman dan pengetahuan supaya hasil penelitian valid. Pengelola wisata kampung warna-warni bapak Ismael Marzuki, sangat diperlukan karena untuk mengetahui upaya perbaikan lingkungan, persepsi dan partisipasi masyarakat terhadap upaya perbaikan lingkungan, faktor pendorong dan penghambat patisipasi masyarakat dalam upaya perbaikan lingkungan kampung warna-warni, dan keterkaitan spasial pengembangan Jodipan terhadap aspek kehidupan masyarakat Pengelola wisata. Pengelola wisata sangat membantu sekali dalam analisis data karena bisa membandingkan atau membedakan dari hasil jawaban informan yang lainnya. Tokoh masyarakat terdiri dari 9 orang informan yaitu ibu Arningsih sebagai penjual bakso, ibu Ning penjaga tiket masuk, bapak Tefa sebagai tukang parkir, ibu Marni penjaga toilet, ibu Wiwik pedagang minuman dan rokok, bapak Joko pemandu wisata, ibu Maria penjual sosis, ibu Ismah penjual es cream, dan bapak Wempa penjual sembako. Dari 9 tokoh masyarakat kampung warna-warni bahwa sangat diperlukan karena sebagai informan kunci, untuk mengetahui upaya perbaikan lingkungan, persepsi dan partisipasi masyarakat terhadap upaya perbaikan lingkungan, faktor pendorong dan penghambat patisipasi masyarakat dalam upaya perbaikan lingkungan kampung warna-warni, dan keterkaitan spasial pengembangan Jodipan terhadap aspek kehidupan masyarakat Pengelola wisata. masyarakat juga sebagai informan kunci dalam penelitian karena bisa mengetahui dan menambahkan wawasan terhadap upaya perbaikan lingkungan Jodipan. Jadi jumlah keseluruhan dari daftar pertanyaan pedoman wawancara untuk ketua RW 02, pengelola wisata dan masyarakat terdiri dari 17 pertanyaan.

\section{Analisis data}

Di dalam buku Qualitative Data Analysis (Miles \& Huberman, 1987) ada empat komponen penting dalam teknik menganalisis data dan ketiga komponen ini yang di gunakan oleh penulis, yaitu:

\section{Pengumpulan data (Data collection)}

Pada analisis model pertama dilakukan pengumpulan data hasil wawancara, hasil observasi, dan berbagai dokumen berdasarkan kategorisasi yang sesuai dengan masalah penelitian yang kemudian dikembangkan penajaman data melalui pencarian data selanjutnya. Mereduksi data (Data reduction)

Istilah reduksi dapat berarti pengurangan, potongan. reduksi data berarti upaya untuk mengurangi atau melakukan pemotongan data dari setumpuk data atau informasi yang dipandang kurang relevan dengan permasalahan yang dikaji. Menurut Sutopo (1990) reduksi data merupakan proses seleksi, pemfokusan, penyederhanaan dan abstraksi data dari catatan lapangan (field note). Mereduksi data berarti merangkum, memilih hal-hal yang pokok, menfokuskan pada hal-hal yang penting, dicari tema dan polanya dan membuang yang tidak perlu.

Inti dari mereduksi data adalah proses penggabungan dan penyeragaman segala bentuk data yang diperoleh baik dari hasil observasi, hasil wawancara ataupun hasil study dokumentasi untuk menjadi satu bentuk tulisan (script) yang akan dianalisis, sehingga data yang telah direduksi akan memberikan gambaran yang lebih jelas dan mempermudah peneliti untuk melakukan pengumpulan data selanjutnya dan mencari bila diperlukan. Dengan demikian penulis di sini melakukan pereduksian data dari semua hasil observasi, semua hasil wawancara dan semua hasil study dokumen tasi dengan berbentuk script sejak sebelum memasuki lapangan, selama di lapangan dan setelah selesai di lapangan.

Menyajikan data (Display data) 
Setelah semua data telah diformat berdasarkan instrument pengumpulan data dan telah berbentuk tulisan (script) langkah selanjutnya adalah melakukan display data atau penyajian data. Penyajian data adalah sekumpulan informasi yang tersusun yang memberi kemungkinan untuk menarik kesimpulan dan pengambilan tindakan. Pada prinsipnya display data adalah mengolah data setengah jadi yang sudah seragam dalam bentuk tulisan dan sudah memiliki alur tema yang jelas.

Dalam proses display data terdapat 3 tahapan, yaitu: kategori tema, sub kategori tema dan proses pengkodean. Data yang sudah ada disusun dengan menggunakan teks yang bersifat naratif, selain itu dapat berupa matriks, grafik, networks, dan chart". Namun, karena penelitian ini kualitatif, maka data yang digunakan adalah dengan bentuk teks yang bersifat naratif karena penulis di sini dapat menguasai data dan tidak terpaku pada tumpukan data, serta memudahkan penulis untuk merencanakan tindakan selanjutnya (Miles dan Huberman). Verifikasi data

Verifikasi data/kesimpulan merupakan tahap terakhir dalam rangkaian analisis data kualitatif menurut model interaktif yang dikemukakan oleh Miles \& Huberman (1984). Kesimpulan dalam analisis data kualitatif menjurus pada jawaban dari pertanyaan penelitian yang diajukan dan mengungkap "what" dan "how" dari penelitian. Verifikasi dimaksudkan untuk menghasilkan kesimpulan yang valid. Oleh karena itu, penulis di sini melakukan peninjauan ulang terhadap kesimpulan dengan cara memverifikasi kembali catatan-catatan selama penelitian dan mencari pola, tema, model, hubungan dan persamaan untuk diambil sebuah kesimpulan.

\section{Hasil dan Pembahasan}

\section{Upaya perbaikan lingkungan kawasan kampung warna-warni terhadap perbaikan lingkungan}

\section{Bekerja sama mengecat dinding}

Masyarakat di Jodipan bekerjasama dalam upaya perbaikan lingkungan. Hal ini dapat dilihat dari Jodipan menjadi lebih terawat dan bersih sehingga menjadi objek wisata yang banyak di minati oleh wisatan hal ini merupakan bentuk dari kerjasama masyarakat dalam upaya perbaikan lingkungan. berikut penjelasan yang disampaikan oleh informan bahwa:

"Salah satu yang dilakukan yaitu membantu mengecat di setiap rumah jadi semua saya (Bapak Marzuki) masyarakat Jodipan bekerja sama dan membantu pengecatan kampung warna-warni. Tujuannya adalah supaya kampung warna-warni terlihat indah, menarik dan banyak di gemari oleh pengunjung sehingga menjadi objek wisata yang terkenal”. (Ismael Marzuki, 2018).

Soerjono Soekanto (2006), mengemukan bahwa kerjasama suatu usaha bersama antara orang perorangan atau kelompok untuk mencapai tujuan tertentu. Upaya perbaikan lingkungan masyarakat Kelurahan Jodipan dilakukan dengan bervariasi diantaranya bekerjasama mengecat dinding, membersihkan lingkungan, memasang keramik, membangun jembatan Embong, mengecat pagar beraneka warna, memasang hiasan pintu dengan lukisan dan membuat tempat untuk berfoto (selfie).

\section{Membersihkan lingkungan}

Kampung Jodipan menjadi lebih terawat dan bersih. Di sepanjang bantaran sungai hampir tidak ada lagi sampah-sampah yang berserakan, warna-warnanya yang mencolok juga 
membuat kesan kampung yang bersih. Hal ini dijelaskan oleh informan pada saat melakukan wawancara, hal ini dijelaskan bahwa:

"Dengan membersihkan lingkungan yang kotor misalnya membuang sampah ke sungai lagi, selain itu juga mengecat dinding, pagar, tangga, tembok dengan bermacam-macam warna dan juga menambahkan lukisan di dinding maupun menghiasi depan pintu dengan hal-hal yang unik seperti menghiasi dengan di beri bunga maupun lukisannya”.(Ismah, 2018).

Supardi (2003), lingkungan hidup adalah jumlah semua benda hidup dan benda mati serta seluruh kondisi yang ada di dalam ruang yang di tempati. Perubahan yang cukup signifikan tersebut, memberikan dampak yang besar terhadap lingkungan, sosial, dan ekonomi. Membersihkan lingkungan merupakan usaha yang dilakukan masyarakat Jodipan untuk menjadikan Jodipan sebagai objek wisata seperti sekarang ini yang di namakan kampung warna-warni yang banyak di minati oleh para wistawan.

\section{Memasang keramik di kawasan kampung warna-warni}

Memasang keramik merupakan partisipasi masyarakat Jodipan dalam upaya perbaikan lingkungan. semua masyarakat Jodipan berpartisipasi dalam memasang keramik di kawasan kampung warna-warni baik perempuan maupun laki-laki. Hal ini dijelaskan oleh informan bahwa:

"Dengan ikut berpartisipasi dalam upaya perbaikan lingkungan misalnya memasang keramik di kawasan kampung warna-warni tujuannya adalah untuk menjadikan objek wisata yang maju”. (Arningsih, 2018).

Mengenai partisipasi sangat berpengaruh besar pada pelakunya, sehingga partisipasi yang dilakukan oleh warga akan membuat diri menjadi lebih berkembang dan bisa diterima di lingkungan tempat tinggal, di lingkungan sekolah, bahkan pada seorang yang memiliki keterbatasan (disability) pun mampu membuat pelaku partisipasi menjadi lebih percaya diri dan ikut andil dalam kegiatan bermasyarakat.

\section{Membangun jembatan Embong dan mengecat pagar beraneka warna}

Masyarakat Jodipan melakukan kegiatan bervariasi dalam upaya perbaikan lingkungan salah satunya Membangun jembatan Embong dan mengecat pagar beraneka warna. Masyarakat Jodipan telah berhasil mengubah image Jodipan sebagai objek wisata. hal ini di jelaskan oleh informan bahwa:

"Dengan membersihkan lingkungan kawasan kampung warna-warni, mengecat setiap rumah, mengecat setiap tangga, memasang keramik di setiap rumah, membangun jembatan embong, menghiasai tempat untuk berfoto, mengecat pagar dengan bunga dan mengecat beraneka warna di pagar kawasan kampung warna-warni”. (Marni,2018).

Ibu marni ikut berpartisipasi dalam membangun jembatan Embong dan mengecat pagar beraneka warna. Hal ini dilakukan oleh ibu Marni karena mempunyai tujuan supaya Jodipan menjadi objek wisata dan lingkungan yang bersih.

\section{Memasang hiasan pintu dengan lukisan}


Berbagai macam upaya perbaikan lingkungan yang telah dilakukan masyarakat Jodipan yaitu dengan Memasang hiasan pintu dengan lukisan. Masyarakat Jodipan antusiame dalam upaya perbaikan lingkungan. Hal ini dijelaskan oleh informan bahwa:

"Saya (Ibu Wiwik) ikut berpartisipasi dalam upaya perbaikan lingkungan misalnya mengecat rumah, dan memasang hiasan pintu dengan lukisan, membersihkan lingkungan, jadi saya (Ibu Wiwik) selalu ikut dalam upaya perbaikan lingkungan, apa yang dikerjakan warga lainnya saya (Ibu Wiwik) selalu ikut untuk berpartisipasi”. (Wiwik, 2018).

Ibu Wiwik memiliki antusiame yang tinggi dalam upaya perbaikan lingkungan yaitu dengan berpartisipasi dalam memasang hiasan pintu dengan lukisan.

\section{Membuat tempat untuk berfoto (selfie)}

Upaya perbaikan lingkungan juga dilakukan oleh masyarakat Jodipan yaitu berpartisipasi dalam membuat tempat untuk berfoto (selfie). Hal ini dijelaskan oleh informan bahwa:

"Melakukan kegiatan seperti membersihkan lingkungan, mengecat dinding, memasang keramik di jalan dan menbuat tempat untuk berfoto, tujuannya untuk meningkatkan perekonomian saya (Bapak Joko), yang dulunya perekonomian saya (Bapak Joko) rendah dan sekarang sudah lumayan bisa membantu perekonomian saya (Bapak Joko) dengan adanya upaya perbaikan lingkungan Jodipan, selain itu juga manfaatnya adalah untuk kesehatan karena jika lingkungan bersih, kesehatan juga terjaga”. (Joko, 2018.)

Uphoff dan Cohen (1980), menyatakan partisipasi dalam tahap pengambilan keputusan (Decision making), tahapan implementasi (Implementation), tahap menikmati keuntungan (Benefit), dan tahap partisipasi dan evaluasi. Sebelum adanya upaya perbaikan lingkungan, Kelurahan Jodipan dulunya permukiman kumuh, perbedaan yang signifikan terlihat antara kampung Jodipan dahulu dan sekarang. Kampung Jodipan dahulu tidak terawat dengan baik, banyaknya sampah yang berserakan pada bantaran sungai, susunan rumah yang bertumpuk, hingga tembok dan atap rumah yang tidak terawat dan tampak usang karena tidak dilakukan perbaikan, sedangkan saat ini sudah bermetamorfosis menjadi kampung yang lebih indah dan menarik.

\section{Persepsi masyarakat kampung warna-warni terhadap upaya perbaikan lingkungan}

\section{Membawa perubahan}

Persepsi masyarakat Jodipan dengan adanya upaya perbaikan lingkungan yaitu membawa perubahan Jodipan menjadi lingkungan bersih dan objek wisata. Hal ini dijelaskan oleh informan yaitu bahwa:

"Kondisi Jodipan sekarang ini adalah banyak mengalami perubahan yaitu Jodipan menjadi objek wisata yang terkenal dan banyak diminati oleh para wisatawan, selain itu juga kondisi Jodipan sekarang yaitu dengan lingkungan yang bersih dan cat yang beraneka warna pada dinding rumah, tangga, pagar, dan juga memiliki lukisan yang indah dan menarik seperti lukisan manusia bersayap”.(Soni Parin, 2018).

Jalaludin Rachmat dalam bukunya Psikologi Komunikasi (2004), persepsi merupakan pengalaman tentang objek, atau hubungan yang diperoleh dengan menyimpulkan informasi dan menafsirkan pesan. Jalaludin juga menambahkan bahwa persepsi memberikan makna pada stimulus indrawi (sensory stimulus). Adelia Aldilla (2012), yang berjudul Persepsi Masyarakat Terhadap Pengembangan Kawasan Ekowisata Islami Curug Cigangsa. (Studi kasus: Kampung Batusuhunan, Kelurahan Surade, Kabupaten Sukabumi, Provinsi Jawa 
Barat). Dimana terdapat beberapa persepsi masyarakat terhadap upaya perbaikan lingkungan diantaranya, membawa perubahan, lingkungan bersih, pemandangan menarik, dan lingkungan indah. Jadi Jodipan bisa membawa perubahan dengan adanya upaya perbaikan lingkungan yang di lakukan masyarakat Jodipan.

\section{Lingkungan bersih}

Keberlangsungan pemeliharaan kebersihan Jodipan diharapkan terus berlangsung dan bahkan diharapkan akan semakin bersih dan indah pada masa yang akan datang. Untuk itu perlu dikembangkan persepsi dan partisipasi yang baik terhadap pengelolaan lingkungan. Hal ini dijelaskan oleh informan bahwa:

"Keluruhan Jodipan sekarang ini, menjadi objek wisata yaitu yang kampung warna-warni sehingga banyak di kunjungi oleh wisatawan dan menjadi objek wisata yang indah dan menarik oleh para wisatawan yang datang dan lingkungan yang bersih”.(Ismael Marzuki, 2018).

Persepsi bapak Ismael Marzuki mengenai upaya perbaikan lingkungan yaitu menjadikan Jodipan sebagai lingkungan yang bersih. Lutfi Kristiana Palupi (2014), lingkungan adalah studi tentang gejala dan masalah kehidupan manusia yang ditinjau antar hubungannya dengan lingkungan tempat kehidupan. Lingkungan merupakan pengkajian praktis tentang masalah kehidupan dan masalah lingkungan, yang menerapkan konsep dan prinsip ekologi serta prinsip dan konsep Ilmu Sosial.

\section{Pemandangan menarik}

Persepsi masyarakat terhadap upaya perbaikan lingkungan ini merupakan suatu hal penting mengingat masyarakat merupakan aktor utama dari upaya perbaikan lingkungan di keluruhan Jodipan. Persepsi masyarakat dalam upaya perbaikan lingkungan Jodipan berbeda-beda antara individu satu dengan individu yang lain salah satunya pemandangan menarik. Hal ini dijelaskan oleh informan bahwa:

"Lingkungan bersih dan pemandangan yang menarik misalnya dengan warna cat yang berwarna-warni di setiap rumah Jodipan”.(Ismah, 2018).

Lutfi Kristiana Palupi (2014), lingkungan adalah studi tentang gejala dan masalah kehidupan manusia yang ditinjau antar hubungannya dengan lingkungan tempat kehidupan. Lingkungan merupakan pengkajian praktis tentang masalah kehidupan dan masalah lingkungan, yang menerapkan konsep dan prinsip ekologi serta prinsip dan konsep Ilmu Sosial. Jadi pemandangan menarik menjadi salah satu incaran masyarakat Jodipan untuk menjadikan Jodipan sebagai objek wisata.

\section{Lingkungan indah}

Masyarakat Jodipan memiliki tujuan untuk menjadikan Jodipan sebagai lingkungan yang indah. Hal ini dilihat dari persepsi masyarakat. Hal ini di jelaskan oleh informan bahwa: 
"Lingkungannya indah dan bersih dan rumah-rumahnya bertembok, berlantai keramik dan gang-gangnya juga rapi berkat batu hias yang di pasang sehingga enak dipandang, sejuk, indah dan bersih dengan kondisi sekarang ini". (Wiwik, 2018).

Lutfi Kristiana Palupi (2014), lingkungan adalah studi tentang gejala dan masalah kehidupan manusia yang ditinjau antar hubungannya dengan lingkungan tempat kehidupan. Lingkungan merupakan pengkajian praktis tentang masalah kehidupan dan masalah lingkungan, yang menerapkan konsep dan prinsip ekologi serta prinsip dan konsep Ilmu Sosial.

\section{Partisipasi masyarakat kampung warna-warni terhadap upaya perbaikan lingkungan}

\section{Keterlibatan mengecat dinding}

Masyarakat Jodipan berpartisipasi dalam upaya perbaikan lingkungan yaitu keterlibatan mengecat dinding. Semua masyarakat ikut berpartisipasi baik perempuan maupun laki-laki. Hal ini dijelaskan oleh informan bahwa:

\footnotetext{
"Keterlibatan saya (Bapak Soni) adalah bahwa saya (bapak Soni) ikut berpartisipasi dalam upaya perbaikan lingkungan kampung warna-warni contohnya saya (Bapak Soni) bepartisipasi dalam mengecat dinding, pagar, tangga dan menambahkan fasilitas kampung warna-warni misalnya tempat-tempat untuk berfoto".(Soni Parin, 2018).
}

Bapak Soni Parin berpendapat bahwa keterlibatanya dalam berpartisipasi terhadap upaya perbaikan lingkungan yaitu dengan antusiasme yang tinggi. Tujuannya untuk menjadikan Jodipan sebagai objek wisata. Uphoff dan Cohen (1980), partisipasi dalam tahap pengambilan keputusan (Decision making), tahapan implementasi (Implementation), tahap menikmati keuntungan (Benefit), dan tahap partisipasi dan evaluasi. Adanya partisipasi masyarakat di Kelurahan Jodipan ini sebagain besar didukung oleh masyarakat di kelurahan Jodipan, hal ini terbukti dari tingginya partisipasi masyarkat yaitu berpartisipasi dalam mendukung kegiatan upaya perbaikan lingkungan dan masyarakat yang mengaku berperan aktif dalam membersihkan lingkungan, keterlibatan mengecat dinding, Keterlibatan mengecat tembok, dan keterlibatan menambah fasilitas berfoto dan membersihkan lingkungan dalam upaya perbaikan lingkungan Kelurahan Jodipan. Kelurahan Jodipan sudah merasakan manfaat secara nyata dan perekonomian pun sudah meningkat, masyarakat tersebut yang telah berpartisipasi dalam upaya perbaikan lingkungan.

\section{Keterlibatan mengecat pagar beraneka warna}

Dalam partisipasi, pemerintah dan masyarakat juga mengambil keputusan dalam upaya perbaikan lingkungan contoh bentuk partisipasi dengan membersihkan lingkungan, mengecat dinding, pagar dengan beraneka warna, membuat tempat untuk selfie dan membangun jembatan Embong yaitu dengan bekerja sama, selain itu juga dengan adanya partisipasi, masyarakat Jodipan juga menikmati keuntungan. Hal ini dijelaskan oleh informan dengan penjelasan:

"keterlibatan saya (Bapak Marzuki) dalam kampung warna-warni yaitu bahwa masyarakat bekerjasama dalam membangun kampung warna-warni contohnya adalah mengecat pagar kampung warna-warni jadi semua saya (bapak Marzuki) dan masyarakat terlibat berpartisipasi baik pria maupun wanita”. (Ismail Marzuki, 2018). 
Partisipasi masyarakat dalam upaya perbaikan lingkungan bervariasi dengan atntusiame masyarakat yang tinggi dalam upaya perbaikan lingkungan. Rahmawati dan Sumarti (2011), kemauan dan kemampuan merupakan potensi yang dimiliki setiap individu ataupun kelompok, sedangkan kesempatan akan lebih dipengaruhi oleh situasi lingkungan yang berasal dari luar individu ataupun kelompok. Tingkat kemauan dapat ditentukan oleh faktor psikologis individu seperti harapan akan imbalan ataupun manfaat yang akan didapatkan. Lugiarti (2004), menambahkan bahwa faktor yang menentukan tingkat kemauan juga berasal dari motif dan kebutuhan. Dorongan seseorang melakukan sesuatu untuk mencapai suatu tujuan sangat tergantung kepada seberapa besar harapan yang dimilikinya.

\section{Keterlibatan membuat tempat untuk berfoto dan membersihkan lingkungan}

Partisipasi masyarakat menjadi model dalam upaya perbaikan lingkungan yang sesuai bagi Jodipan, dalam mengidentifikasi partisipasi masyarakat perlu adanya penstrukturan mengenai tingkat dan bentuk dari partiispasi dalam masyarkat. Faktor yang mendorong partisipasi masyarakat dalam upaya perbaikan lingkungan yaitu pengetahuan terhadap program merupakan pemahaman masyarakat bisa saja dipengaruhi oleh lingkungan masyarakat itu sendiri. Hal ini dijelaskan oleh informan yaitu bahwa:

"Ikut berpartisipasi dalam upaya perbaikan lingkungan misalnya berpartisipasi dalam mengecat, membuat tempat untuk berfoto dan membersihkan lingkungan”.(Arningsih, 2018).

Ibu Arningsih juga berpartisipasi dalam upaya perbaikan lingkungan yaitu dengan keterlibatan membuat tempat untuk berfoto dan membersihkan lingkungan. tujuannya adalah untuk menjadikan Jodipan sebagai objek wisata dan lingkungan yang bersih sehinggan enak untuk di pandang dengan cat beraneka warna pada setiap rumah. Farizi Ramadhan dan Parfi Khadiyanto (2014), adanya partisipasi masyarakat di dalam objek wisata menjadi model yang dipandang ideal bagi objek wisata yang banyak pengunjung wisatawan. Partisipasi masyarakat menjadi model dalam upaya perbaikan lingkungan yang sesuai bagi Jodipan, dalam mengidentifikasi partisipasi masyarakat perlu adanya penstrukturan mengenai tingkat dan bentuk dari partiispasi dalam masyarkat. Faktor yang mendorong partisipasi masyarakat dalam upaya perbaikan lingkungan yaitu pengetahuan terhadap program merupakan pemahaman masyarakat bisa saja dipengaruhi oleh lingkungan masyarakat itu sendiri. Jadi adanya kecenderungan masyarakat berpartisipasi dalam upaya perbaikan lingkungan dari seberapa jauh pengetahuan masyarakat mengenai kampung warna-warni Jodipan.

\section{Faktor pendorong partisipasi masyarakat dalam upaya perbaikan lingkungan kampung warna-warni}

\section{Pemahaman}

Pemahaman masyarakat bisa saja dipengaruhi oleh lingkungan masyarakat itu sendiri. Kita akan melihat adanya kecenderungan masyarakat berpartisipasi dalam upaya perbaikan lingkungan dari seberapa jauh pengetahuan masyarakat mengenai Kawasan kampung warnawarni. Hampir seluruh masyarakat Kawasan kampung warna-warni pada umumnya sudah mengetahui objek wisata dan paham bahwa Jodipan sudah diangkat menjadi objek Wisata di keluruhan Jodipan Kota Malang, Pemahaman masyarakat akan upaya perbaikan lingkungan pun dirasa sudah sangat baik. Hal ini dijelaskan oleh informan bahwa: 
"Upaya perbaikan lingkungan misalnya pemahaman saya (Bapak Soni) dan masyarakat Jodipan pada umumnya sudah mengetahui cara membersihkan lingkungan, mengecat dinding, pagar, dan tangga dengan beraneka warna sehingga menjadi faktor pendorong masyarakat Jodipan dengan pemahaman dan pengetahuannya”. (Soni Parin, 2018).

Ariyani (2007), menyatakan terdapat tiga prasyarat agar seseorang dapat berpartisipasi dalam pembangunan yaitu adanya kesadaran pada diri yang bersangkutan tentang adanya kesempatan, adanya kemauan yang merupakan sikap positif terhadap sasaran partisipasi, serta dukungan oleh kemampuan berinisiatif untuk bertindak dengan komitmen.

\title{
Pengetahuan
}

Pengetahuan masyarakat Jodipan mengenai upaya perbaikan lingkungan sudah cukup aktif. pengetahuan adalah informasi atau maklumat yang diketahui atau disadari masyarakat dalam upaya perbaikan lingkungan, pengetahuan ini bisa di dapatkan di media ataupun informasi lewat masyarakat secara langsung mengenai faktor pendorong partisipasi masyarakat terhadap upaya perbaikan lingkungan. Hal ini dijelaskan oleh informan bahwa:

\begin{abstract}
"Pengetahuan terhadap program Pemahaman dan kesadaran saya (Bapak Marzuki) dan masyarakat bisa saja dipengaruhi oleh lingkungan saya (Bapak Marzuki) dan masyarakat itu sendiri. Kita akan melihat adanya kecenderungan saya (Bapak Marzuki) dan masyarakat berpartisipasi dalam upaya perbaikan lingkungan dari seberapa jauh pengetahuan saya (Bapak Marzuki) dan masyarakat mengenai Kawasan kampung warna-warni. Hampir seluruh saya (bapak Marzuki) dan masyarakat Kawasan kampung warna-warni pada umumnya sudah mengetahui objek wisata dan paham bahwa Jodipan sudah diangkat menjadi objek Wisata di keluruhan Jodipan Kota Malang, Pemahaman saya (Bapak Marzuki) dan masyarakat akan upaya perbaikan lingkungan
\end{abstract} pun dirasa sudah sangat baik”.(Ismail Marzuki, 2018).

Lugiarti (2004), menambahkan bahwa faktor yang menentukan tingkat kemauan juga berasal dari motif dan kebutuhan. Dorongan seseorang melakukan sesuatu untuk mencapai suatu tujuan sangat tergantung kepada seberapa besar harapan yang dimilikinya. Jadi faktor pendorong partisipasi masyarakat adalah pengetahuan masyarakat terhadap upaya perbaikan lingkungan.

\section{Mendapatkan keuntungan dengan berjualan}

Masyarakat Jodipan juga mendapatkan keuntungan dengan adanya upaya perbaikan lingkungan yaitu keuntungan yang dirasakan oleh masyarakat adalah bisa berjualan di kawasan kampung warna-warni. Dengan adanya wisatawan yang datang masyarakat Jodipan bisa memanfaatkan keuntungan dengan berjualan. Hal ini dijelaskan oleh informan bahwa:

\footnotetext{
"Bisa mendapatkan keuntungan misalnya bisa berjualan makanan atau minuman, negatifnya terganggunya ketentraman karena selalu ramai pengunjung yang datang”.(Tefa, 2018).
}

Bapak Tefa bisa memanfaatkan dengan berjualan dengan adanya wisatawan yang datang. Hal ini bisa mendapatkan keuntungan yang cukup untuk memenuhi kebutuhan sehari-hari bapak Tefa, Rahmawati dan Sumarti (2011), kemauan dan kemampuan merupakan potensi yang dimiliki setiap individu ataupun kelompok, sedangkan kesempatan akan lebih dipengaruhi oleh situasi lingkungan yang berasal dari luar individu ataupun kelompok. Tingkat kemauan dapat ditentukan oleh faktor psikologis individu seperti harapan akan imbalan ataupun manfaat yang akan didapatkan.

\section{Untuk meningkatkan perekonomian}


Dengan adanya upaya perbaikan lingkungan masyarakat berpartisipasi dalam mengubah Jodipan sebagai objek wisata. dari hal ini masyarakat Jodipan mendapatkan keuntungan yaitu meningkatnya perekonomian masyarakat. Perekonomian masyarakat sebelum terbentuknya kampung warna-warni masih rendah tetapi dengan adanya upaya perbaikan lingkungan perekonomian masyarakat meningkat. Hal ini dijelaskan oleh informan bahwa:

"Untuk meningkatkan perekonomian yaitu perekonomian saya (Bapak Soni) juga meningkat karena saya (Bapak Soni) dapat membuka usaha kecil-kecilan disepanjang jalan utama kampung Jodipan ini. Tanpa disadari, banyaknya dampak positif tersebut membuat kampung ini menjadi salah satu ikon kota Malang. Dampak negatifnya adalah ketentraman saya (Bapak Soni) terganggu misalnya kalau ada yang meninggal tentu memerlukan situasi yang tentram dan dengan kondisi yang tidak ramai”. (Soni Parin, 2018).

Jadi dengan adanya partisipasi masyarakat dalam upaya perbaikan lingkungan bahwa meningkatnya perekonomian masyarakat Jodipan.

\section{Faktor penghambat partisipasi masyarakat dalam upaya perbaikan lingkungan kampung warna-warni}

\section{Pekerjaan di luar Jodipan}

Latar belakang pekerjaan masyarakat menjadi faktor penghambat pasrtisipasi masyarakat dalam upaya perbaikan lingkungan Jodipan. Walaupun mungkin saja memang ada beberapa yang karena latar belakang pekerjaan dan berbagai kesibukan jadi tidak memiliki waktu luang untuk berpartisipasi pada upaya perbaikan lingkungan Jodipan, dan pekerjaan masyarakat menjadi faktor penghambat. Hal ini dijelaskan oleh informan bahwa:

"Faktor yang menghambat partisipasi saya (Bapak Soni) adalah latar belakang pekerjaan karena saya (Bapak Soni) yang sibuk dengan pekerjaan sehingga saya (Bapak Soni) untuk ikut berpartisipasi menjadi terhambat dalam upaya perbaikan lingkungan Jodipan tetapi saya (Bapak Soni) tatap meluangkan dan membagikan waktu saya (Bapak Soni) untuk terlibat partisipasi dalam upaya perbaikan lingkungan”.'(Soni Parin, 2018).

Lugiarti (2004), menambahkan bahwa faktor yang menentukan tingkat kemauan juga berasal dari motif dan kebutuhan. Dorongan seseorang melakukan sesuatu untuk mencapai suatu tujuan sangat tergantung kepada seberapa besar harapan yang dimilikinya. Jadi pasrtisipasi masyarakat dalam upaya perbaikan lingkungan Kelurahan Jodipan. Walaupun mungkin saja memang ada beberapa yang karena latar belakang pekerjaan dan berbagai kesibukan jadi tidak memiliki waktu luang untuk berpartisipasi pada upaya perbaikan lingkungan Kelurahan Jodipan, dan pekerjaan masyarakat menjadi faktor penghambat.

\section{Dana}

Dana merupakan faktor penghambat masyarakat dalam upaya perbaikan lingkungan. masyarakat sering mengalami kekurangan dana dalam membeli beraneka cat maupun untuk menambahkan fasilitas kampung warna-warni. Hal ini dijelaskan oleh informan bahwa:

"Kendalanya adalah dari segi dana yang diperlukan dalam upaya perbaikan lingkungan misalnya untuk membeli cat sangat memerlukan dana biaya yang banyak”.(Arningsih, 2018).

Rahmawati dan Sumarti (2011), kemauan dan kemampuan merupakan potensi yang dimiliki setiap individu ataupun kelompok, sedangkan kesempatan akan lebih dipengaruhi 
oleh situasi lingkungan yang berasal dari luar individu ataupun kelompok. Tingkat kemauan dapat ditentukan oleh faktor psikologis individu seperti harapan akan imbalan ataupun manfaat yang akan didapatkan. Dana biaya juga merupakan faktor penghambat partisipasi dalam upaya perbaikan lingkungan karena dalam upaya perbaikan lingkungan sering mengalami kekurangan dana biaya. Misalnya dalam membeli cat untuk mengecat semua rumah kawasan kampung warna-warni Jodipan. kesalahpahaman pendapat karena berbagai macam karakteristik masyarakat tentu akan berbagai macam berpendapat, ini merupakan faktor penghambat partisipasi masyarakat Kelurahan Jodipan.

\section{Kesalahpahaman/beda pendapat}

Dalam berpartisipasi terhadap upaya perbaikan lingkungan masyarakat Jodipan mengalami kesalahpahaman/ beda pendapat yaitu sebagai faktor penghambat partisipasi masyarakat. Hal ini dijelaskan oleh informan bahwa:

"Kesalahpahaman misalnya berbeda pendapat yang $A$ ingin seperti ini dan yang b maunya seperti ini tapi itu semua bisa di selesaikan secara baik-baik, tetapi dengan berbeda pendapat ada baiknya karena semua ide bisa tertuang di situ dan disatukan atau di pakai semua sehingga kawasan kampung warna-warni memiliki keunikankeunikan yang indah dan menarik dengan menerapkan setiap pendapat yang berbeda. Masalah lainnya juga di dana yang di perlukan”.(Wiwik, 2018).

Jadi masyarakat Jodipan dalam upaya perbaikan lingkungan sering mengalami kekurangan dana biaya karena untuk membeli cat beraneka warna memerlukan dana yang cukup banyak.

\section{Kesibukan pekerjaan diluar Jodipan dan menjemput anak sekolah}

Dengan adanya upaya perbaikan lingkungan bahwa masyarakat juga merasakan adanya faktor penghambat partisipasi yaitu kesibukan pekerjaan diluar Jodipan dan menjemput anak sekolah. Hal ini dijelaskan oleh informan bahwa:

"Kesibukan misalnya pekerjan diluar Jodipan dan menjemput anak ke sekolah dan mengantarnya karena saya (Bapak Wempe) mempunyai 2 orang anak jadi yang 1 masih SD dan yang SMP selain itu juga saya (Bapak Wempe) harus bekerja yaitu lokasinya yang lumayan jauh. Tetapi walaupun dengan kesibukan saya (Bapak Wempe) seperti itu saya (Bapak Wempe) tetap bisa membagi waktu saya (Bapak Wempe) untuk ikut berpartisipasi dalam upaya perbaikan lingkungan Jodipan”.(Wempe, 2018).

kesibukan pekerjaan diluar Jodipan dan menjemput anak sekolah. karena berbagai macam karakteristik masyarakat tentu akan berbagai macam kesibukan, ini merupakan faktor penghambat partisipasi masyarakat Kelurahan Jodipan.

\section{Keterkaitan spasial pengembangan kampung warna-warni terhadap aspek kehidupan masyarakat}

\section{Munculnya usaha-usaha kecil sepanjang jalan Jodipan}

Keterkaitan spasial pengembangan kampung warna warni terhadap aspek kehidupan masyarakat mengenai dampak positif ditimbulkan dengan adanya wisata kampung warnawarni Jodipan. Hal ini dijelaskan oleh informan bahwa:

\footnotetext{
"Dampak positif adalah di bidang perekonomian yaitu perekonomian saya (Bapak Soni) juga meningkat karena saya (Bapak Soni) dapat membuka usaha kecil-kecilan disepanjang jalan utama kampung Jodipan ini. Tanpa disadari, banyaknya dampak positif tersebut membuat kampung ini menjadi salah satu ikon kota Malang.
} 
Dampak negatifnya adalah ketentraman saya (Bapak Soni) terganggu misalnya kalau ada yang meninggal tentu memerlukan situasi yang tentram dan dengan kondisi yang tidak ramai". (Soni Parin, 2018).

Mubyarto dalam Lisnini (2005), dalam upaya meningkatkan kualitas sumber daya manusia, prioritas utama perlu diarahkan kepada peningkatan penghasilan melalui perluasan kesempatan kerja. Penghasilan masyarakat Jodipan yang berwirausahan di rumahnya sendiri dapat mensejahterakan keluarganya dan meningkatkan perekonomian. Masyarakat yang berjualan di rumahnya tidak perlu melakukan pekerjaan lain di luar rumah, karena penghasilan yang didapatkan mampu memberi keuntungan yang dapat digunakan untuk mencukupi kebutuhan keluarganya, keterkaitan spasial pengembangan kampung warna warni terhadap aspek kehidupan masyarakat mengenai dampak positif dan negatif ditimbulkan dengan adanya wisata kampung warna-warni Jodipan.

\section{Terganggunya ketentraman}

Analisis asosiasi keruangan di Kelurahan Jodipan yaitu terganggunya ketentraman masyarakat. Dengan adanya keragaman pengunjung yang datang merupakan suatu kondisi dalam masyarakat dimana terdapat perbedaan dalam berbagai bidang terutama ras, agama, dan budaya sehingga membuat ketentraman masyarakat terganggu. Hal ini dijelaskan oleh informan bahwa:

"Dampak negatifnya adalah terganggunya lalu lintas kendaraan karena area parkir wisata Jodipan disisi jalan raya. Positifnya adalah bisa memanfaatkan usaha untuk berjualan karena dapat membantu dan meningkatkan perekonomian misalnya berjualan makanan atau minuman”.(Soni Parin, 7 0ktober 2018).

Keragaman dalam masyarakat ialah sebuah keadaan yang menunjukan perbedaan yang cukup banyak macam atau jenisnya memiliki makna sebagai suatu kondisi dalam masyarakat dimana terdapat perbedaan-prbedaan. Jadi terganggunya ketentraman masyarakat. Dengan adanya keragaman pengunjung yang datang merupakan suatu kondisi dalam masyarakat dimana terdapat perbedaan dalam berbagai bidang terutama ras, agama, dan budaya sehingga membuat ketentraman masyarakat terganggu.

\section{Kesimpulan}

Masyarakat Kelurahan Jodipan dalam upaya perbaikan lingkungan sudah berperan aktif dan juga sudah bervariasi kegiatan masyarakat dalam upaya perbaikan lingkungan misalnya dalam membersihkan lingkungan, mengecat dinding, mengecat pagar, membangun jembatan Embong, dan membuat tempat untuk selfie. Persepsi masyarakat terhadap upaya perbaikan lingkungan Kelurahan Jodipan Kota Malang yakni sebagian besar informan menyatakan upaya perbaikan lingkungan kelurahan Jodipan berpotensi untuk dikembangkan menjadi objek wisata, selain itu untuk kebersihan lingkungan Kelurahan Jodipan. Partisipasi Masyarakat di Kelurahan Jodipan dalam upaya perbaikan lingkungan, telah di mulai sejak awal upaya perbaikan lingkungan di Kelurahan Jodipan pada tahun 2016, upaya perbaikan lingkungan menjadi salah satu bentuk dari adanya partisipasi masyarakat di Kelurahan Jodipan. Saran penulis untuk tindak lanjut bagi penelitian selanjutnya agar lebih memperhatikan waktu penelitian. Waktu penelitian diharapkan tidak dilakukan pada waktu responden sibuk, sehingga hasil wawancara mendapatkan hasil yang lebih akurat. 


\section{Ucapan Terimakasih}

Saya berterimakasih kepada Universitas Kanjurahan Malang, masyarakat kampung warnawarni sebagai tempat untuk menuntut ilmu, dan yang telah mendukung, membantu kelancaran dalam menyelesaikan penulisan artikel ini.

\section{Daftar Rujukan}

Aldilla, Adelia (2012) Persepsi Masyarakat Terhadap Pengembangan Kawasan Ekowisata Islami Curug Cigangsa. Jawa Barat.

Ariyani (2007) Partisipasi Masyarakat dalam Pelaksanaan PNPM Mandiri Perdesaan dan Efektifitasnya Terhadap Ketahanan Ekonomi Keluarga (Studi di Kecamatan Kalanganyar, Kabupaten Lebak, Banten)", dalam Jurnal Ketahanan Nasional, Vol XIX No. 2.

Cohen dan Uphoff (1980) Analisis partisipasi masyarakat dalam pengembangan. desa wisata kandri kota Semarang: Jurnal Partisipasi Masyarakat, Pengembangan, Desa Wisata.

Freud (2002) Masyarakat yang majemuk Jakarta: Jurnal spasial, vol 8. No 2.

Huberman dan Miles (1984) Metodologi Penelitian Kualitatif, (Bandung: PT Remaja Rosdakarya).

Huberman dan Miles (1987) Metodologi Penelitian Kualitatif, (Bandung: PT Remaja Rosdakarya).

Khadiyanto Parfi dan Ramadhan, Farizi (2014) Partisipasi Masyarakat Dalam Mendukung Kegiatan Pariwisata, Yogyakarta.

Lisnini dan Mubyarto (2005). Upaya kualitas sumber daya manusia, jurnal. Program Studi Desain Interior, Fakultas Seni dan Desain Universitas Kristen Petra, Surabaya.

Lugiarti (2004) faktor pendorong partisipasi masyarakat. Kabupaten Maluku Tenggara kecamatan kei kecil kabupaten maluku tenggara

Nabila Rizki, Aulia dan Yuniningsih, Tri (2009) Analisis partisipasi masyarakat dalam pengembangan desa wisata, Kandri Kota Semarang.

Palupi Kristiana, Lutfi (2014) Persepsi Masyarakat Terhadap Pengelolaan Lingkungan Hidup, Yogyakarta.

Pidarta Made (2009) Partisipasi Masyarakat dalam Pelaksanaan PNPM Mandiri Perdesaan dan Efektifitasnya Terhadap Ketahanan Ekonomi Keluarga (Studi di Kecamatan Kalanganyar, Kabupaten Lebak, Banten)", dalam Jurnal Ketahanan Nasional, Vol XIX No. 2.

Rachmat Jalaludin (2004) Persepsi Masyarakat Terhadap Potensi Objek Daya Tarik Wisata Pantai di Kecamatan Kei Kecil Kabupaten Maluku Tenggara. Jurnal: persepsi masyarakat terhadap potensi objek daya tarik wisata pantai. Kecamatan kei kecil kabupaten maluku tenggara, vol, Volume VI, No 2.

Soekanto Soerjono (2006) kerjasama dalam peorangan atau kelompok. Bandung: penelitian.

Sumarti dan Rahmawati (2011) Persepsi Masyarakat Terhadap Potensi Objek Daya Tarik Wisata Pantai di Kecamatan Kei Kecil Kabupaten Maluku Tenggara. Jurnal: persepsi masyarakat terhadap potensi objek daya tarik wisata pantai. Kecamatan kei kecil kabupaten maluku tenggara, vol, Volume VI, No 2.

Sumaryadi (2010) Partisipasi masyarakat desa dalam program desa siaga di desa. Bandung kecamatan PLayen kabupaten Gunung Kidul Provinsi daerah istimewa Yogyakarta. Kebijakan dan management publik.

Supardi (2003) Laporan Standar Pelayanan Minimal (SPM) Bidang Lingkungan Hidup. Daerah Istimewa Yogyakarta Tahun 2012. Yogyakarta: BLH DIY. 
Sutopo (1990) Metodologi Penelitian Kualitatif, (Bandung: PT Remaja Rosdakarya).

Yunus Sabari, Hadi (1987) Pendekatan analisis keruangan. Jakarta: Jurnal: pendekatan analisis keruangan, vol 3. No 4. 